\title{
KEBIJAKAN BAILOUT CENTURY: DISKRESI ATAU KRIMINALISASI KEBIJAKAN
}

\author{
Lily Evelina Sitorus*
}

\author{
* Mahasiswa Program Pascasarjana Fakultas Hukum Universitas Indonesia \\ Korespondensi: 1i15779@gmail.com \\ Naskah dikirim: 8 Februari 2016 \\ Naskah diterima untuk diterbitkan: 7 Maret 2016
}

\begin{abstract}
Century bailout policy is the government's discretion. However, when there is resistance in the Parliament, this policy is a problem that until now has not as well satisfy the parties. On the other hand, the economic crisis is a reality that is happening in the community. Government as the policy makers feel they have the authority as stipulated in the legislation in force. Therefore, the decision to prosecute government policy is regarded as a form of criminalization policies. This study tried to find a middle ground on the issue. The standpoint of administrative law is used as an analysis in finding the right solution. It was with the aim of no longer controversial policies issued by the government is considered to be detrimental to the country's financial and creating legal certainty in the implementation.
\end{abstract}

Keywords: discretion, policy, bailout century

\begin{abstract}
Abstrak
Kebijakan bailout Century merupakan diskresi pemerintah. Namun, ketika terjadi penolakan di DPR, kebijakan ini menjadi permasalahan yang sampai saat ini belum juga memuaskan para pihak. Di sisi lain, krisis ekonomi merupakan suatu kenyataan yang terjadi di masyarakat. Pemerintah sebagai pihak pengambil kebijakan merasa memiliki kewenangan seperti diatur dalam peraturan perundang-undangan yang berlaku. Oleh karena itu, keputusan untuk mengadili kebijakan pemerintah dianggap sebagai bentuk kriminalisasi kebijakan. Penelitian ini mencoba mencari jalan tengah terhadap permasalahan tersebut. Sudut pandang hukum administrasi negara digunakan sebagai analisa dalam mencari solusi yang tepat. Hal itu dengan tujuan tidak ada lagi kebijakan kontroversial yang dikeluarkan pemerintah yang dianggap dapat merugikan keuangan negara dan menciptakan kepastian hukum dalam pelaksanaannya.
\end{abstract}

Kata kunci: diskresi, kebijakan, bailout century 


\section{Pendahuluan}

Keputusan untuk melakukan penyelamatan yang bersifat sistemik sering memicu perdebatan antara pihak yang pro dan kontra. Pembuat kebijakan selalu dihadapkan pada pilihan-pilihan yang sulit bahkan seringkali harus menghadapi dilemma untuk mengambil tindakan atau tidak. Dalam kasus krisis di Eropa tahun 2010 di Spanyol, Bank Sentral Spanyol mengambil alih sebuah bank lokal kecil yang bernama Bank Caja Sur. Bank ini tidak termasuk bank yang dikategorikan berdampak sistemik jika dilihat dari keterkaitan dan skalanya, sehingga seharusnya tidak menimbulkan masalah too big too fail. Namun, menurut Chatib Basri, alasannya sederhana dalam situasi panik, maka penutupan satu bank dapat berakibat sistemik. ${ }^{1}$

Pada tahun 2008 ketika Amerika memutuskan untuk membiarkan Lehman Brothers bangkrut, pendapat konvensional menyatakan bahwa keputusan itulah yang menyebabkan terjadinya krisis finansial yang dikenal sebagai 'resesi terbesar' dalam perekonomian Amerika. ${ }^{2}$ Namun, menurut Michel, pada kenyataannya walau kebangkrutan Lehman mengirimkan sinyal masalah pada investor di pasar keuangan, hal itu bukan merupakan penyebab dari krisis. Kegagalan kebijakan pembuat keputusan yang lebih memilih membailout bank kecil seperti Bear Stearns adalah penyebabnya. ${ }^{3}$

Kebijakan bail-out century merupakan diskresi pemerintah dibawah menteri keuangan dalam mengatasi gejolak perekonomian saat itu. Menurut Eko Prasojo, dasar hukum pemberian diskresi tersebut yang seharusnya ditelaah secara detail kepada Menkeu dan Gubernur BI khususnya mengenai keberadaan KSSK sesuai PERPU No 4/2008 tentang JPSK. ${ }^{4}$ Lebih lanjut, Eko menyarankan agar persoalan century tidak hanya ditinjau melalui perspektif hukum pidana dan tata negara saja, melainkan lebih fokus pada hukum administrasi negara karena dalam perspektif administrasi negara, setiap keputusan pemerintah harus bisa dipertanggungjawabkan secara legal dan profesional.

Keputusan pemerintah yang dimaksud dalam penelitian ini adalah kebijakan Menkeu dan Gubernur BI atas pengucuran dana ke century yang dianggap berada dalam kondisi krisis dan berdampak sistemik yang seharusnya bisa dipertanggungjawabkan secara profesional. Akuntabilitas legal akan menjawab apakah diskresi yang dipergunakan benar-benar memiliki dasar dan

\footnotetext{
${ }^{1}$ A. Prasetyantoko, Ponzi Ekonomi: Prospek Indonesia di Tengah Instabilitas Global, "Kompas", Jakarta, November 2010.

2 Norbert J. Michel, Lehman Brothers Bankruptcy and the Financial Crisis: Lesson Learned, diunduh dari: <http://www.heritage.org/research/reports/2013/09/lehman-brothers-bankruptcy-and-thefinancial-crisis-lessons-learned\#_ftn1>, diakses tanggal 10 Februari 2015.

${ }^{3}$ The Bear Stearns bailout set the expectation that Lehman would also be bailed out, setting up investors and creditors for a fall. At the very least, those with a stake in Lehman surely expected the government to minimize their losses. Thus, the inconsistent treatment of the two investment banks-not simply the act of letting Lehman file bankruptcy-was the main problem. Ibid.
}

${ }^{4}$ Centurygate: Mengurai Konspirasi Penguasa-Pengusaha, “Kompas”, Jakarta, April 2010. 
sumber kewenangan. Hal ini menurut Eko dapat diuji dengan asas-asas umum pemerintahan yang baik. ${ }^{5}$

Kontroversi dimulai ketika Dewan Perwakilan Rakyat (DPR) menolak Peraturan Pemerintah Pengganti UU (PERPU) No 4 Tahun 2008 tentang Jaring Pengaman Sistem Keuangan (JPSK). PERPU yang merupakan dasar hukum bagi kebijakan Bailout Bank Century tersebut ditolak DPR dengan alasan ada bahaya yang bisa timbul terhadap Anggaran Pendapatan dan Belanja Negara (APBN), tetapi tidak bisa diambil tindakan hukum terhadap pejabat yang telah menyebabkan bahaya itu. ${ }^{6}$

Dua hal utama yang menjadi alasan penolakan PERPU JPSK adalah kedudukan Komite Stabilitas Sektor Keuangan (KSSK) yang dominan dalam menetapkan kondisi perekonomian tergolong krisis dan kewenangan yang diberikan kepada Menkeu untuk mengeluarkan dana ekstra atas nama krisis, tanpa meminta izin kepada DPR. ${ }^{7}$ Kedua hal tersebut menurut Juru bicara Fraksi Partai Golkar Taufik Hidayat, dapat menyebabkan imunitas pejabat publik yang menjalankan PERPU. Selain itu, PERPU tentang JPSK menyulitkan kontrol publik dengan menempatkan pengambil keputusan hanya diserahkan kepada Menteri keuangan dan Gubernur BI, sehingga berpotensi terjadi moral hazard. ${ }^{8}$

Penelitian ini juga diharapkan dapat memberikan jawaban atas permasalahan yang secara nyata terungkap dalam persidangan kasus tindak pidana korupsi yang melibatkan mantan ketua KSSK yang menyatakan bahwa adanya keinginan untuk mencabut keputusan KSSK ketika dampak krisis sudah mulai melemah. Namun, tidak adanya aturan hukum untuk melakukan tindakan tersebut membuat keputusan KSSK tetap diberlakukan. Hal ini merupakan kelemahan yang seharusnya dapat dihindari.

Keputusan KSSK memberikan peluang untuk menyalurkan kebijakan bailout Bank Century sebanyak 4 kali. Dalam kesaksiannya, ${ }^{9}$ Sri Mulyani menyatakan bahwa dampak krisis sudah mulai melemah pada bulan Februari 2009. Jika keputusan KSSK saat itu dapat dicabut maka penyaluran kebijakan bailot Bank Century tahap ketiga dan keempat dapat dihindari. Berikut tabel Penyertaan Modal Sementara yang dilakukan oleh LPS dalam rangka menyehatkan bank Bank Century: ${ }^{10}$

\footnotetext{
${ }^{5}$ Ibid.

${ }^{6}$ Enam dari 10 fraksi di DPR menolak Peraturan Pemerintah Pengganti Undang-Undang tentang Jaring Pengaman Sistem Keuangan, diunduh dari: <http://bisniskeuangan.kompas.com/read/ 2008/12/18/01121851>, diakses tanggal 10 Maret 2015.

${ }^{7}$ Dalam pasal 29 disebutkan bahwa Menteri Keuangan, Gubernur Bank Indonesia, dan/atau pihak yang melaksanakan tugas sesuai Peraturan Pemerintah Pengganti Undang-Undang ini tidak dapat dihukum karena telah mengambil keputusan atau kebijakan yang sejalan dengan tugas dan wewenangnya sebagaimana dimaksud dalam Peraturan Pemerintah Pengganti Undang-Undang ini.

${ }^{8}$ Op. Cit.

${ }^{9}$ Dalam persidangan tindak pidana korupsi, Jumat, 2 Mei 2014.
} 


\begin{tabular}{|c|c|c|c|c|}
\hline NO & TAHAP & $\begin{array}{l}\text { TANGGAL } \\
\text { PENYALURAN }\end{array}$ & $\begin{array}{l}\text { JUMLAH } \\
\text { (Rp) }\end{array}$ & DASAR \\
\hline 1 & I & 24 NOV-1 DES 2008 & $\begin{array}{l}2,776 \\
\text { (triliun) }\end{array}$ & $\begin{array}{l}\text { RDK NO 043/RD- } \\
\text { LPS/2008, } 23 \text { NOV } \\
2008\end{array}$ \\
\hline 2 & II & 9 DES-30 DES 2008 & $\begin{array}{l}2,201 \\
\text { (triliun) }\end{array}$ & $\begin{array}{lll}\text { RDK } & \text { NO } \\
\text { 050/RDK- } & \\
\text { LPS/2008, } 5 & \text { DES } \\
2008 & & \\
\end{array}$ \\
\hline 3 & III & 4 FEB-24 FEB 2009 & $\begin{array}{l}1,155 \\
\text { (triliun) }\end{array}$ & 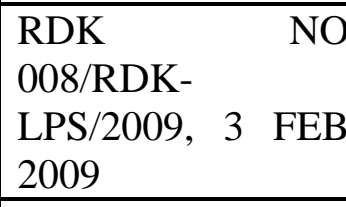 \\
\hline 4 & IV & 24 JULI 2009 & $\begin{array}{l}630,221 \\
\text { (milyar) }\end{array}$ & $\begin{array}{l}\text { RDK } \\
\text { 039/RDK- } \\
\text { LPS/2009, } 30 \text { JUNI } \\
2009\end{array}$ \\
\hline & & TOTAL & $\begin{array}{l}6,762 \\
\text { (triliun) }\end{array}$ & \\
\hline
\end{tabular}

Keputusan KSSK dapat dikategorikan sebagai Keputusan TUN sesuai pasal 1 ayat (3) UU tentang PTUN No 5 Tahun 1986 yaitu suatu penetapan tertulis yang dikeluarkan oleh Badan atau Pejabat TUN yang berisi tindakan hukum TUN yang berdasarkan peraturan perundang-undangan yang berlaku, yang bersifat konkret, individual, dan final, yang menimbulkan akibat hukum bagi seseorang atau badan hukum perdata. ${ }^{11}$ Pengecualian terhadap keputusan TUN terdapat pada Pasal 49 yang menyatakan bahwa pengadilan tidak berwenang memeriksa, memutus, dan menyelesaikan sengketa TUN tertentu dalam hal keputusan yang disengketakan itu dikeluarkan:

a. Dalam waktu perang, keadaan bahaya, keadaan bencana alam, atau keadaan luar biasa yang membahayakan, berdasarkan peraturan perundang-undangan yang berlaku;

b. Dalam keadaan mendesak untuk kepentingan umum berdasarkan peraturan perundang-undangan yang berlaku.

${ }^{10}$ Audit BPK yang diolah dari berbagai sumber, <http://bisnis.news.viva.co.id/news/read/108042rincian_23_aliran_dana_lps_untuk_Century>, diakses tanggal 8 Februarui 2015.

11 Pasal 87 UU No 30 Tahun 2014 tentang Administrasi Pemerintahan menyebutkan dengan berlakunya Undang-Undang ini, Keputusan Tata Usaha Negara sebagaimana dimaksud dalam UndangUndang Nomor 5 Tahun 1986 tentang Peradilan Tata Usaha Negara sebagaimana telah diubah dengan Undang-Undang Nomor 9 Tahun 2004 dan UndangUndang Nomor 51 Tahun 2009 harus dimaknai sebagai: a. penetapan tertulis yang juga mencakup tindakan faktual; b. Keputusan Badan dan/atau Pejabat Tata Usaha Negara di lingkungan eksekutif, legislatif, yudikatif, dan penyelenggara negara lainnya; c. berdasarkan ketentuan perundang-undangan dan AUPB; d. bersifat final dalam arti lebih luas; e. Keputusan yang berpotensi menimbulkan akibat hukum; dan/atau f. Keputusan yang berlaku bagi Warga Masyarakat. 
Penelitian ini memiliki keutamaan dalam hal kebaruan dan hasil yang bisa diterapkan secara global. Kebijakan penanganan krisis bukan hanya terkait administrasi negara tertentu melainkan juga keuangan global. Dampak sistemik sebagai salah satu syarat penanganan krisis sudah banyak diteliti namun belum menghasilkan suatu solusi yang memuaskan dalam memecahkan masalah. Oleh karena itu, melalui pendekatan hukum diharapkan penelitian ini dapat menjadi suatu solusi yang lebih objektif dalam mencari jalan keluar dalam masalah yang multidisiplin.

Penelitian ini juga sangat terkait dengan disertasi yang sedang dikerjakan peneliti. Disertasi tersebut nantinya akan sangat membantu dalam permasalahan kebijakan di tanah air yang saat ini sedang mengalami berbagai sorotan dikarenakan hubungannya dengan potensi kerugian negara. Penelitian ini juga diharapkan dapat menjadi sumbangan berharga bagi pembahasan RUU JPSK yang merupakan landasan hukum bagi kebijakan penanganan krisis di masa datang dan harmonisasi antara UU Administrasi Pemerintahan dan UU PTUN dalam menilai kewenangan pejabat negara ketika melakukan diskresi.

\section{Civil Law vs Common Law}

Dalam sistem hukum Indonesia, judicial review terhadap putusan administrasi negara dimungkinkan. MA pernah melakukan penafsiran hukum mengenai hal itu ketika melakukan pengujian terhadap peraturan kebijakan yang berbentuk surat edaran, yaitu terhadap Surat Edaran Dirjen Mineral Batubara dan Panas Bumi Nomor 03/31/DJB/2009. ${ }^{12}$ Konsep judicial review terhadap administrative action juga telah dipraktikkan sejak lama di Singapura. Berdasarkan doktrin 'ultra vires', bahwa judicial review "is not concerned with the decision but with the decision-making process". Hal ini seperti terlihat dalam pertimbangan hakim Andrew Ang J dalam perkara ACC v CIT. ${ }^{13}$

Walaupun lebih dikenal dalam tradisi Anglo Saxon, doktrin 'ultra vires', menjadi prinsip utama dalam hukum administrasi yang menunjukkan betapa pentingnya hukum memberikan batasan bagi kekuasaan. Ultra vires mengacu pada tindakan diluar kewenangan yang ada pada pembuat keputusan. Walaupun hakim dapat menggunakan doktrin ini, namun pada prakteknya mulai dibatasi untuk judicial review. Oleh karena itu, judical review lebih tepat

\footnotetext{
12 Berdasarkan Putusan Mahkamah Agung Republik Indonesia Perkara No. 23 P/HUM/2009, MA menyatakan SE No. 03/31/DJB/2009 bertentangan dengan Undang-Undang Nomor 4 Tahun 2009 tentang Pertambangan Mineral dan Batubara dan karenanya tidak sah dan tidak berlaku untuk umum. Putusan MA tersebut menunjukkan adanya interpretasi yang memperluas ruang lingkup jenis peraturan perundang-undangan tetapi juga sekaligus menyamarkan batasan konsep peraturan kebijakan.

${ }^{13}$ It is well established that in judicial review, the court is concerned not with the merits of a decision but the process by which the decision has been made... This is because judicial review is not an appeal from a decision and the court cannot substitute its discretion for that of the public body nor can it quash a decision on the basis that the court would not have arrived at that decision or that some other decision would have been a better one. lihat Thio Li-ann, "The Theory and Practice of Judicial Review of Administrative Action in Singapore", SAL Conference 2011 — Singapore Law Developments (20062010).
} 
digunakan untuk membatasi diskresi dan regulasi pembuat keputusan oleh pengadilan. ${ }^{14}$

Judicial review pertama kali timbul dalam praktik hukum di Amerika Serikat yang secara eksplisit tidak diatur dalam konstitusi negara tersebut. Lahirnya judicial review ke dalam tatanan hukum Amerika Serikat melalui putusan Mahkamah Agung (Supreme Court) Amerika Serikat dalam perkara "Marbury vs. Madison" pada tahun 1803 yang saat itu John Marshal sebagai Ketua Mahkamah Agung Amerika Serikat. ${ }^{15}$ Putusan Mahkamah Agung Amerika Serikat dalam kasus "Marbury vs. Madison" ini pada intinya memuat bahwa Pasal 13 Judiciary Act (UU Kekuasaan Kehakiman) tahun 1789 Amerika Serikat bertentangan dengan konstitusi negara tersebut. Sebenarnya tidak ada ketentuan yang jelas dalam konstitusi negara Amerika Serikat yang memberikan kewenangan kepada lembaga kekuasaan kehakiman (Mahkamah Agung) untuk melakukan judicial review. ${ }^{16}$

Menurut John Marshall, ketentuan Pasal 13 Judiciary Act tahun 1789 merupakan penambahan kewenangan Supreme Court. Jika hal tersebut diberlakukan, maka dengan sendirinya mengubah ketentuan konstitusi melalui undang-undang biasa. Oleh karena itu, ketentuan tersebut harus dinyatakan tidak sah dan bertentangan dengan konstitusi yang merupakan "the supreme law of the land". ${ }^{17}$

Diskresi merupakan bagian utama yang tidak dapat dipisahkan dari aturan hukum. Hal itu dikarenakan sistem hukum kontemporer menjadi sangat bergantung pada kewenangan yang melekat pada pejabat hukum dan administrasi untuk mencapai tujuan legislasi. Hal ini tidak bisa dihindari karena menerjemahkan aturan menjadi tindakan-proses membuat abstraksi

${ }^{14}$ Ultra vires refers to action which is outside-or in excess of-powers of decision making body. While judges continue to use the terms ultra vires, it is nowadays too limited a term to encompass the whole ambit of judicial review. It may be preferable, therefore, to regard judicial review as the control of discretion and the regulation of the decision making process by the courts. Lihat Hilaire Barnett, "Constitutional and Administrative Law", (London: Routledge and Cavendish, 2006), hal. 750.

${ }^{15}$ Effendi, Op. Cit.

${ }^{16}$ Peristiwa pengangkatan sekelompok hakim baru di larut malam, kelak dinamakan the midnight judges, oleh presiden lama, John Adams, dilakukan menjelang serah terima jabatan kepada presiden terpilih, Thomas Jefferson, memicu kemarahan salah seorang hakim baru itu, William Marbury yang merasa keberatan tatkala surat pengangkatannya selaku hakim tidak diberikan oleh Secretary of State, James Madison, berdasarkan perintah Presiden Thomas Jefferson. Pemerintah baru bermaksud membatalkan pengangkatan hakim-hakim baru di malam larut itu. William Marbury memohonkan kepada Supreme Court agar mengeluarkan Writ of Mandamus guna memerintahkan Secretary of State James Madison menyerahkan surat pengangkatan dirinya. Berdasarkan Judiciary Act 1789, perkara yang diajukan Marbury termasuk original jurisdiction dari Supreme Court sehingga tidak perlu melalui pengadilan yang lebih rendah. Majelis Hakim Agung dibawah Chief Justice John Marshall memutus perkara dimaksud dengan cara pengujian materiil undang-undang yakni mengadakan judicial review terhadap undang-undang yang dipandang bertentangan dengan konstitusi. Sejak putusan Chief Justice John Marshall dimaksud, dunia peradilan Amerika dibekali kewenangan judicial review terhadap undangundang termasuk perkara orang perorangan biasa. lihat kata pengantar Laica Marzuki dalam Zainal Arifin Hoesein, "Judicial Review di Mahkamah Agung RI Tiga Dekade Pengujian Peraturan Perundangundangan” (Jakarta: PT RajaGrafindo Persada, 2009), hal. viii.

\footnotetext{
${ }^{17}$ Effendi, Op. Cit.
} 
menjadi kenyataan-melibatkan interpretasi dan pilihan. Menurut Dworkin, diskresi merupakan konsep relatif yang mengambil arti dari konteks aturan atau standar dan eksis sebagai 'as an area left open by a surrounding belt of restriction'. ${ }^{18}$

Sebelum tahun 1969, ketika Kenneth Culp Davis pertama kali mempublikasi bukunya yang berjudul Discretionary Justice, diskresi seringkali dipertimbangkan sebagai sarana yang lebih diinginkan dalam personalisasi penerapan hukum. Selain itu juga untuk memperlunak kekakuan yang timbul dari waktu ke waktu akibat penerapan hukum tersebut. Namun, setelah publikasi Davis, diskresi menjadi bahasan kritis terkait kelemahan dan ketidakadilan yang mungkin diciptakannya. ${ }^{19}$

Jika semua keputusan yang melibatkan keadilan terhadap para pihak dibuat dalam satu skala, dengan aturan hukum yang kaku di sebelah kiri dan diskresi bebas di sebelah kanan, sedangkan yang berada diantara keduanya yang melibatkan hukum, prinsip, standar dan diskresi umum adalah keadilan maka dalam skala mana ketidakadilan berada? ${ }^{20}$

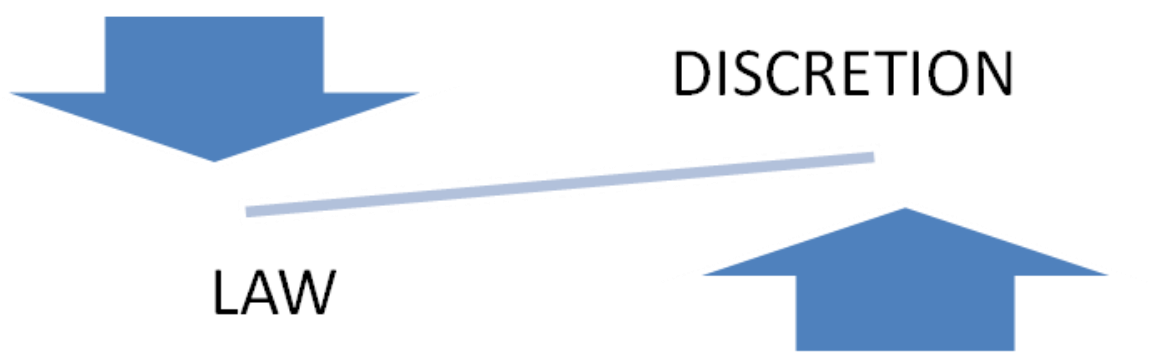

Ketidakadilan menurut Davis akan sering muncul di posisi kanan karena hukum dan prinsip yang ada tidak banyak menyediakan arahan sedangkan emosi pembuat keputusan dapat mempengaruhi keputusan yang diambil termasuk didalamnya pengaruh politik atau favoritisme dan ketidaksempurnaan dari manusia seringkali terefleksi dalam pilihan yang ada. Namun, Davis juga menemukan bahwa yurisprudensi banyak mengabaikan keadilan karena lebih cenderung mempertimbangkan legislator dan hakim daripada administrator, eksekutif, polisi dan jaksa. Selain itu, yurisprudensi juga memahami perlunya diskresi akan tetapi lebih banyak memilih penerapan hukum yang kaku. ${ }^{21}$

18 Keith Hawkins, "The Use of Legal Discretion: Perspectives from Law and Social Science dalam Oxford Socio-Legal Studies: 'The Uses of Discretion"”, (USA: Oxford University Press, 1992), Op. Cit., hal. 14.

${ }^{19}$ Ibid.

${ }^{20}$ Menurut Davis, pejabat dan hakim akan berada pada posisi kiri karena pembentukan hukum umumnya tidak melibatkan emosi dan pembuat keputusan jarang melakukan kesalahan ketika berhadapan dengan hukum yang kaku. Posisi tengah akan lebih seimbang karena prinsip atau aturan lain yang ada akan membuat diskresi terbatas atau terkontrol. lihat Kenneth Culp Davis, "Discretionary Justice: A Preliminary Inquiry", (USA: University of Illinois Press, 1971), hal. v. 
Hukum administrasi banyak didominasi dengan istilah diskresi. Istilah tersebut seringkali menentukan fungsi suatu organ dan menggambarkan peran dari pengadilan dalam melakukan pengujian. Oleh karena itu, sangat penting bagi pengadilan memahami diskresi administrasi baik untuk mengevaluasi kinerja suatu organ maupun memahami fungsi pengadilan itu sendiri. Istilah diskresi setidaknya memiliki 5 pengertian dalam hukum administrasi: ${ }^{22}$

a. Kewenangan untuk membuat keputusan yang bersifat individu dalam penerapan aturan yang umum disebut sebagai "individualizing discretion";

b. Kebebasan untuk mengisi kekosongan dalam kewenangan delegasi dengan tujuan melakukan fungsi administrasi yang sudah ditetapkan disebut sebagai "executing discretion";

c. Kekuasaan untuk mengambil tindakan dalam rangka tujuan bersama disebut sebagai "policymaking discretion";

d. Jika pengujian tidak diijinkan, maka organ yang membuat keputusan dianggap sedang melakukan "unbridled discretion";

e. Sedangkan jika pengujian secara prinsip tidak diijinkan maka organ pembuat keputusan dianggap sedang melakukan "numinous discretion".

Fungsi pengadilan yang berbeda berhubungan dengan pembedaan dari tipe diskresi diatas. Meski salah satu dari tujuan negara adalah negara hukum, tetapi arah atau sasaran utamanya adalah negara kesejahteraan (welfare state). Oleh karena itu pejabat eksekutif yang lebih banyak bersentuhan dengan pelaksanaan undang-undang tidak dapat dibatasi untuk tidak bertindak, ketika terjadi kekosongan hukum (wetvacuum) dan adanya peraturan pelaksanaan undang-undang yang perlu ditafsirkan (interpertate). Namun tetap saja perlu diperhatikan bahwa meski itu adalah tindakan diskresi pejabat maka harus dipertanggungjawabkan secara hukum dan moral. ${ }^{23}$

Dalam Seminar Ketatanegaraan yang membahas masalah "Indonesia Negara Hukum" pada bulan Juni 1966 di Jakarta, Oemar Seno Adji menegaskan bahwa, "pada asasnya dan pada umumnya segala perbuatan yang menyangkut dan merugikan setiap orang ataupun hak-haknya dapat diawasi oleh Pengadilan sedangkan review tersebut dapat disalurkan melalui Pengadilan Tata Usaha atau melalui pengadilan-pengadilan biasa." 24

Keperluan adanya satu instansi Peradilan di Indonesia yang khusus diserahi memutus persoalan-persoalan dibidang hukum tata pemerintahan juga diutarakan oleh Sarono dihadapan Musyawarah Nasional PERSAHI di Parapat awal Agustus 1972 yaitu, "didalam bidang hukum administrasi negara mudah

${ }^{21}$ Ibid.

${ }^{22}$ Charles H. Koch Jr., “Judicial Review of Administrative Discretion”, (USA: William \& Mary Law School, 1986).

${ }^{23}$ Ibid.

${ }^{24}$ Purbopranoto, Op. Cit. hal. 85. 
berlaku hukum rimba yang bilamana tak diberantas melalui peradilan administrasi yang berani bertindak tegas pasti akan menjurus menjadi semacam "Rule of Law of the Jungle" bukan anarchie semata-mata dan peradilan administrasi negara adalah sarana "control on the administrastion". ${ }^{25}$

Menurut sistem Administrative Law di Anglo Saxon berhubung adanya sistem "judicial review" penetapan peraturan tentang peradilan administrasi yang sifatnya umum rupanya tidak diperlukan. Definisi tentang istilah "judicial review" itu menurut pendapat Robert S. Lorch adalah:

Judicial review is the broad power of any court on judge not only constitutionality but all legal issues affecting not only acts of Congress but of any government official, agency or legislative body. ${ }^{26}$

Pengaturan peradilan administrasi di Indonesia dimulai dalam Undangundang Dasar Sementara 1950 Pasal 108: "Pemutusan tentang sengketa yang mengenai hukum tata usaha diserahkan kepada pengadilan yang mengadili perkara perdata ataupun kepada alat-alat perlengkapan lain...". Berdasarkan adanya ketetapan tersebut, Wirjono Prodjodikoro menyarankan: "oleh karena pasal UUDS membuka dua macam kemungkinan maka diberikan kesempatan kepada pembentuk undang-undang untuk menempuh salah satu dari empat jalan yaitu: ${ }^{27}$

a. Menentukan bahwa segala perkara tata usaha pemerintahan secara peraturan umum diserahkan kepada pengadilan perdata;

b. Menentukan bagi satu macam soal sengketa tertentu bahwa pemutusannya diserahkan kepada pengadilan perdata;

c. Menentukan bahwa segala perkara tata usaha badan pemutus, bukan pengadilan perdata yang dibentuk secara istimewa;

d. Menentukan bagi suatu macam soal tertentu bahwa pemutusannya diserahkan kepada suatu badan pemutus, bukan pengadilan perdata yang dibentuk secara istimewa.

Saat ini pengaturan peradilan administrasi ada dalam UU No 5 tahun 1986 tentang peradilan tata usaha negara yang telah mengalami dua kali perubahan dengan UU No 9 tahun 2004 dan UU no 51 tahun 2009.

Istilah bail-out mulai dikenal ketika krisis ekonomi yang terjadi pada tahun 1997-1998 membuat pemerintah terpaksa mengeluarkan kebijakan BLBI. Jika melihat dari akar permasalahannya, kebijakan ini serupa dengan

\footnotetext{
${ }^{25}$ Ibid.

${ }^{26}$ Pendek kata semua keputusan dari sesuatu alat perlengkapan pemerintahan atau peradilan dapat ditinjau kembali oleh instansi atasan yang berwenang. Hanya dalam praktek sekarang ini menurut Lorch, di Amerika Serikat hal itu belum merupakan satu konsensus umum sehingga sering menimbulkan konflik, "many policies governing judicial review are inconsistent within the fifty states and also between them", lihat bukunya “Democratic Process \& Administrative Law”, Detroit 1969, hal. 158.

${ }^{27}$ Purbopranoto, Op. Cit., hal. 93.
} 
kebijakan yang terjadi ketika hal yang sama menimpa AS. Hal itu tidak bisa dihindari, karena ketika krisis terjadi, Indonesia masih bergantung pada IMF. Model penyelesaian yang kemudian dikenal dengan istilah bailout sesungguhnya bukan hal yang baru dalam wacana keilmuan. Richard Painter, dalam artikelnya tentang masalah ini mengatakan: ${ }^{28}$

When I gave a lecture in 2006 on the 1789 bailout plan, I thought government bailouts of this magnitude and the corruption that came with them were an interesting part of legal history. 2008 and 2009 brought another series of massive federal bailouts. These bailouts are no more compatible with government ethics than was the bailout of 1789 .

Painter lebih lanjut menjelaskan bahwa sesungguhnya kebijakan bailout yang terjadi pada saat ini tidak jauh berbeda dengan yang terjadi pada tahun 1789. Menurutnya, walaupun ada perbedaan, hal itu lebih dikarenakan sistem yang semakin lama semakin berkembang. Saat ini peraturan mengenai konflik finansial dari berbagai kepentingan dan insider trading lebih banyak dari waktu itu, akan tetapi pada praktiknya hal tersebut tidak juga berpengaruh banyak misalnya, kebijakan bailout saat ini lebih bersifat subjektif. Faktanya terbukti ketika pemerintah gagal menjamin Lehman Brothers padahal AIG, lawan dari Lehman Brothers dijamin. ${ }^{29}$

Dalam buku putih yang dikeluarkan oleh Kementerian Keuangan, terlihat bahwa pemerintah sangat berhati-hati dalam usahanya mengatasi krisis tahun 2008 agar tidak mengalami hal yang sama ketika menghadapi krisis tahun 1998. Keputusan KSSK dalam penanganan Bank Century dibuat secara kredibel dan transparan tanpa mempedulikan apa nama bank itu, siapa pemiliknya dan siapa saja nasabahnya. Bank apapun yang mengalami kondisi seperti Bank Century pada saat itu dan dianggap berpotensi menimbulkan kerusakan sistemik terhadap perekonomian Indonesia pasti akan ditangani serupa $^{30}$

Mantan Menteri Keuangan Sri Mulyani selaku pejabat pembuat keputusan bailout Century kembali menegaskan bahwa keputusan pemerintah Indonesia mengucurkan dana talangan sebesar Rp.6,7 triliun untuk menyelamatkan Bank Century pada 2008, merupakan keputusan yang tepat. Menurutnya, keputusan menyelamatkan Bank Century itu didasari untuk menyelamatkan sistem perbankan dan keuangan Indonesia dari ancaman krisis ekonomi dunia. ${ }^{31}$

\footnotetext{
${ }^{28}$ Richard Painter, Bailouts and Government Ethics, diunduh dari: <http://volokh.com/archives/ archive_2009_03_22-2009_03_28.shtml\#1238043132>, diakses tanggal 26 Maret 2009.

${ }^{29}$ Ibid.

${ }^{30}$ Buku putih, Op. Cit., hal. 14

${ }^{31}$ Sri Mulyani menyatakan hal itu saat didengar kesaksiannya dalam persidangan kasus dugaan korupsi Bank Century dengan terdakwa mantan Deputi Gubernur Bank Indonesia, Budi Mulya, Jumat, 2
} 
Wakil Presiden RI Boediono selaku Gubernur BI pada saat kebijakan bailout Century dibuat memberi kesaksian di persidangan yang mengatakan bahwa penyelamatan Bank Century ibarat memadamkan rumah yang terbakar meskipun rumah preman. Berkaca pada krisis tahun 1997-1998, menurut Boediono, akan ada efek domino jika Century tidak diselamatkan pada 2008 itu. Boediono berpendapat, dalam situasi krisis ekonomi 2008, penutupan suatu bank mana pun akan memicu terjadinya rush atau penarikan dana perbankan secara besar-besaran. ${ }^{32}$

Pendapat berbeda datang dari mantan Wakil Presiden saat itu, Jusuf Kalla, yang pada awalnya membenarkan bahwa pada 2007-2008 sedang berlangsung krisis keuangan global. Namun krisis tersebut belum menular ke Indonesia. Jusuf Kalla juga mengaku dirinya mempertanyakan langkah tersebut ketika Menteri Keuangan saat itu Sri Mulyani dan Gubernur Bank Indonesia Boediono melaporkannya belakangan. ${ }^{33}$

\section{Civil Law dalam Sistem Hukum Indonesia}

Negara Republik Indonesia sesuai dengan UUD 1945 beserta penjelasannya merupakan negara hukum ${ }^{34}$ yang berlandaskan Pancasila sebagai ideologi negara. Pringgodigdo dalam pidato pengukuhannya juga menyatakan bahwa Pancasila merupakan sumber dari segala sumber hukum dan UUD 1945 adalah sumber hukum utama. Selain itu, ia juga menyebut RI sebagai negara nasion (kebangsaan) dan negara teritorial modern yang memiliki yuridiksi hukum terhadap wilayah negara. ${ }^{35}$

Mei 2014 di gedung Tipikor, Jakarta. diunduh dari: <http://www.bbc.co.uk/indonesia/berita indonesia/2014/05/140502_sidang> diakses tanggal 2 Maret 2015.

${ }^{32}$ Namun, Majelis Hakim Pengadilan Tindak Pidana Korupsi Jakarta tidak sependapat dengan analogi mantan Gubernur Bank Indonesia tersebut. Menurut hakim, kondisi saat tahun 2008 itu tidak krisis seperti tahun 1997-1998. Masalah yang dihadapi Bank Century bukan karena krisis, melainkan manajemen buruk bank tersebut sejak tahun 2005. Dengan demikian, jika Bank Century tidak diselamatkan, itu tidak akan berdampak pada bank lain. diunduh dari: <http://nasional.kompas.com/ read/2014/07/16/18262601/Hakim.Tepis.Analogi.Boediono>, diakses tanggal 4 Februari 2015.

${ }^{33}$ Kalla juga menyebut skema pemberian dana talangan untuk Bank Century, yang menggunakan sistem blanket guarantee juga melanggar. diunduh dari: <http://www.bbc.co.uk/indonesia /berita_indonesia/2014/05/140508>, diakses tanggal 6 Novermber 2015.

${ }^{34}$ Konsep negara hukum pertama kali diperkenalkan oleh Plato melalui karya tulis ketiganya, Nomoi. Plato mengemukakan bahwa penyelenggaraan negara yang baik ialah yang didasarkan pada pengaturan yang baik. Gagasan ini kemudian dikembangkan lebih lanjut oleh Aristoteles dalam bukunya Politica. Menurut Aristoteles, negara yang baik ialah negara yang diperintah dengan konstitusi dan berkedaulatan hukum. lihat HR. Ridwan, "Hukum Administrasi Negara", (Jakarta: PT Rajagrafindo Perkasa, 2006).

\footnotetext{
${ }^{35}$ Pringgodigdo, Op. Cit.
} 


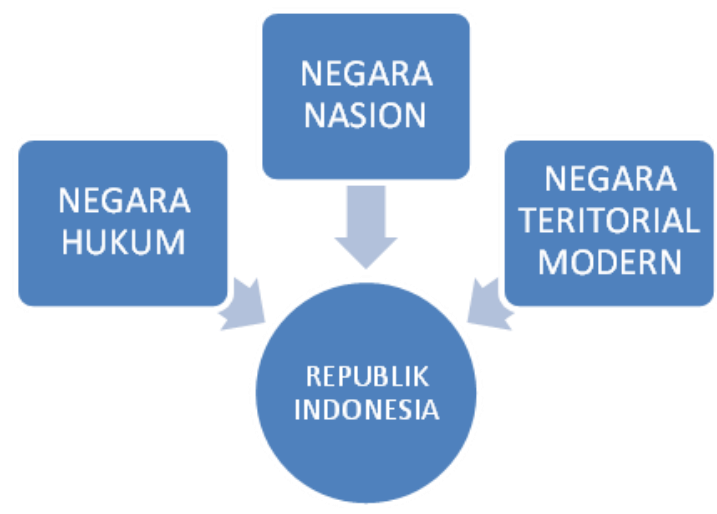

Negara hukum Indonesia menganut sistem civil law ${ }^{36}$ yang berawal pada abad ke-19 dari konsep rechtsstaat yang mulai diperkenalkan oleh Freidrich Julius Stahl dan dilihami oleh Immanuel Kant dengan unsur-unsurnya adalah sebagai berikut:

a. Perlindungan hak-hak asasi manusia;

b. Pemisahan atau pembagian kekuasaan untuk menjamin hak-hak itu;

c. Pemerintahan berdasarkan peraturan perundang-undangan;

d. Peradilan administrasi dalam perselisihan. ${ }^{37}$

Pentingnya unsur-unsur dari negara hukum tersebut yang kemudian menciptakan teori pemisahan kekuasaan. ${ }^{38}$ John Locke adalah seorang tokoh yang dianggap pertama kali memperkenalkan ajaran pemisahan kekuasaan dengan membaginya menjadi:

a. Kekuasaan legislatif (membuat undang-undang);

b. Kekuasaan eksekutif (melaksanakan undang-undang);

c. Kekuasaan federatif (keamanan dan hubungan luar negeri). ${ }^{39}$

${ }^{36}$ Berbeda dengan konsep rechtsstaat di negara civil law, dalam sistem hukum anglo-saxon atau yang lebih dikenal dengan sebutan common law, A.V Dicey memperkenalkan konsep rule of law dengan unsur-unsur sebagai berikut:

a. Supremasi aturan-aturan hukum (supremacy of the law) yaitu tidak adanya kekuasaan sewenang-wenang;

b.Kedudukan yang sama dalam menghadapi hukum (equality before the law);

c. Terjaminnya hak-hak asasi manusia oleh undang-undang.

${ }^{37}$ Ridwan, Op. Cit.

${ }^{38}$ Konsep "pemisahan kekuasaan" menunjuk kepada suatu prinsip organisasi politik. Konsep ini mendalilkan bahwa ketiga bidang kekuasaan itu dapat ditentukan sebagai tiga fungsi negara yang dikoordinasikan secara berbeda, dan bahwa dimungkinkan untuk menentukan batas-batas yang memisahkan masing-masing fungsi ini dari fungsi-fungsi lainnya lihat Hans Kelsen, "General Theory of Law and State" yang dialihbahasakan oleh Somardi "Teori Umum Hukum dan Negara Dasar-dasar Ilmu Hukum Normatif sebagai Ilmu Hukum yang Deskriptif-Empirik", (Jakarta: Bee Media Indonesia, 2007), hal. 329.

\footnotetext{
${ }^{39}$ Ridwan, Op. Cit.
} 
Konsepsi kekuasaan dalam UUD 1945 telah mengakibatkan kuatnya kecenderungan pemerintahan yang berkuasa untuk menafsirkan struktur kekuasaan negara berdasarkan kepentingan kekuasaan yang dimilikinya. Pada saat penyusunan UUD 1945 di BPUPKI dan PPKI, konsep kekuasaan yang dominan adalah konsep tradisional yang mengutamakan keselarasan sosial melalui pola kekeluargaan yang berupa "persatuan antara pemimpin dan rakyat". Konsep ini dituangkan dalam bentuk strukur kenegaraan dengan "concentration of power and responsibility upon the President". Struktur ini mengindikasikan dengan jelas adanya sentralisasi kekuasaan pada Presiden yang potensial untuk melahirkan pemerintahan otokratis. ${ }^{40}$

Padahal di sisi lain, Indonesia justru dirancang sebagai sebuah negara modern yang menghendaki struktur negara yang impersonal. Konsep negara modern yang bersifat impersonal dikemukakan oleh Max Weber ${ }^{41}$ untuk membedakan dari negara tradisional yang didasarkan pada kewenangan personal yang dimiliki oleh para Raja atau kepala suku. Hal ini tentu saja menimbulkan kontradiksi internal dalam UUD 1945 yang pada gilirannya dapat mendorong pada penafsiran secara internal yang bertujuan untuk memperoleh basis legitimasi dari konstitusi. Kenyataan tersebut memperlihatkan dengan jelas bahwa masalah konstitusional di Indonesia bukan hanya berkaitan dengan aspek legalitas tetapi juga menyangkut aspek penafsiran. $^{42}$

Menurut E. Utrecht, sejak negara turut serta secara aktif dalam pergaulan masyarakat, administrasi negara diserahi kewajiban untuk menyelenggarakan kesejahteraan umum. Oleh karena itu, administrasi negara memerlukan kemerdekaan untuk dapat berdiri sendiri terutama dalam penyelesaian tugastugas genting yang peraturan penyelenggaraannya belum ada atau belum dibuat oleh badan-badan kenegaraan yang diserahi fungsi legislatif. ${ }^{43}$

Pemberian kewenangan kepada administrasi negara itu dikenal dengan istilah freies ermessen. Kewenangan untuk bertindak atas inisiatif sendiri mempunyai konsekuensi tertentu dalam bidang legislasi. Bersamaan dengan pemberian kewenangan yang luas untuk bertindak diberikan pula kewenangan untuk membuat instrumen hukumnya. Menurut Utrecht, kekuasaan dalam bidang legislasi ini meliputi:

\footnotetext{
${ }^{40}$ Aidul Fitriciada Azhari,. Penafsiran Konstitusi dan Implikasinya terhadap Pembentukan Sistem Ketatanegaraan Demokrasi atau Otokrasi, Disertasi tidak diterbitkan. Jakarta: Universitas Indonesia, 2005.

${ }^{41}$ The modern state is "action-oriented, anti-essentialist and empirically founded". These are the three crucial traits which accurately capture Weber's notion of the modern state.lihat Andreas Anter, Max Weber's Theory of The Modern State: Origins, Structure and Significance, Reviewed by Christopher Adair-Toteff diunduh dari: <http://theoryculturesociety.org/review-of-max-webers-theory-of-the-modernstate/>, diakses tanggal 1 Oktober 2014.

${ }^{42}$ Azhari, Op. Cit.

${ }^{43}$ E. Utrecht, "Pengantar Hukum Administrasi Negara Indonesia", (Surabaya, Pustaka Tinta Mas,
} 1988,) hal. 11-12. 
a. Kewenangan untuk membuat peraturan atas inisiatif sendiri;

b. Kekuasaan administrasi negara untuk membuat peraturan atas dasar delegasi;

c. Droit function yaitu kekuasaan administrasi negara untuk menafsirkan sendiri berbagai peraturan. ${ }^{44}$

Pembentukan peraturan kebijakan dalam praktik penyelenggaraan pemerintahan merupakan suatu hal yang lumrah terjadi. Menurut Philipus M. Hadjon "pelaksanaan pemerintahan sehari-hari menunjukkan betapa badan atau pejabat tata usaha negara acapkali menempuh berbagai langkah kebijaksanaan tertentu, antara lain menciptakan apa yang kini sering dinamakan peraturan kebijaksanaan (beleidsregel, policy rule)". Peraturan kebijakan adalah wujud formal kebijakan yang ditetapkan oleh pejabat administrasi negara berdasarkan asas diskresi tersebut. ${ }^{45}$

Jika sebelumnya tugas/tujuan pemerintahan itu hanya membuat dan mempertahankan hukum atau dengan kata lain: hanya menjaga ketertiban dan ketenteraman saja maka sekarang tujuan/tugas pemerintahan tidak hanya melaksanakan Undang-undang atau merealisir kehendak negara akan tetapi juga menyelenggarakan kepentingan umum. ${ }^{46}$

Tugas penyelenggaraan kepentingan umum itu dijalankan oleh alat pemerintahan yang berwujud:

a. Seorang petugas atau badan pemerintahan yang berdasarkan peraturan Undang-undang diberi kewenangan untuk menyatakan kehendak pemerintah c.q. penguasa. Oleh karena itu, dilengkapi dengan kewenangan melakukan tindakan-tindakan yang mengikat hukum;

b. Badan pemerintahan yaitu kesatuan hukum yang dilengkapi dengan alat-alat/kewenangan memaksa. ${ }^{47}$

Dalam Green Light Theory, ${ }^{48}$ hukum administrasi ada untuk membantu negara mencapai tujuan kebijakan tertentu. Teori ini cenderung meminimalisir

\footnotetext{
${ }^{44}$ Ibid

45 Arif Christiono Soebroto, Kedudukan Hukum Peraturan/Kebijakan Dibawah Peraturan Menteri Perencanaan Pembangunan Nasional/Kepala Bappenas diunduh dari <http://birohukum.bappenas.go.id>, diakses tanggal 26 Juni2013.
}

${ }^{46}$ Perumusan tujuan pemerintahan menurut Alinea IV Undang Undang Dasar 1945 adalah, "untuk melindungi suatu pemerintah Negara Indonesia yang melindungi segenap bangsa Indonesia dan seluruh tumpah darah Indonesia dan untuk memajukan kesejahteraan umum, mencerdaskan kehidupan bangsa dan ikut melaksanakan ketertiban dunia..." lihat Kuntjoro Purbopranoto, "Beberapa Catatan Hukum Tata Pemerintahan dan Peradilan Administrasi Negara”, (Bandung: Penerbit Alumni, 1985), hal. 41.

${ }^{47}$ Soebroto, Op. Cit.

${ }^{48}$ Red light theorists are committed to a balanced constitution in which executive power, i.e. arbitrary power, is kept in check by Parliament and the courts. This may be described as the "model of laws" approach to administrative law, Green light theorists, represented here by Jennings, Laski and Robson, advocate the use of law to promote "efficient" rule making, and are committed to a "model of government" approach to the administrative process. lihat "The Modern Law Review", Volume 8 issue 
peran pengadilan dan prinsip umum. Hal itu karena teori ini menekankan pada peran yang telah disediakan oleh institusi politik. Teori ini mengembangkan efisiensi dalam proses pemerintahan dan membuat kebijakan lebih efisien serta memberi keadilan pada individu. Teori seperti ini memiliki kecenderungan untuk memilih akuntabilitas politik terhadap hukum. Penganut teori ini tidak ingin pengadilan mencampuri fungsi yang sudah ditetapkan oleh peraturan yang ada dalam wewenang pembuat kebijakan. ${ }^{49}$

Menurut Harlow dan Rawlings, dalam setiap teori hukum administrasi terdapat teori tentang negara. Hal ini berarti tindakan pemerintah merupakan perwakilan dari masyarakat: keduanya merupakan satu konteks yang saling melengkapi. Mengutip Sir Cecil Car yang membuat perumpamaan serupa dalam kuliahnya tentang hukum administrasi di Universitas Harvard pada tahun $1941:^{50}$

We nod approvingly today when someone tells us that, whereas the State used to be merely policeman, judge and protector, it has now become schoolmaster, doctor, house-builder, road-maker, townplanner, public utility supplier and all the rest of it.

Pada akhir abad 19, semua partai politik besar memiliki tujuan praktis dan meninggalkan ide negara penjaga malam. Konsep baru ini jika tidak dinamis maka setidaknya memungkinkan perubahan. Konsepsi lama yang melihat pemerintah sebagai aparatur hukum, penjaga malam sangat bertolak belakang dengan pemerintah sebagai penggerak perubahan. Konsep baru ini tidak hanya membatasi pemerintah untuk mengatur masyarakat, akan tetapi untuk memperbaiki agar lebih maju lagi. Hal inilah yang menurut Dicey merupakan awal dari ide kolektivisme, "the intervention of the State, even at some sacrifice of individual freedom, for the purpose of conferring benefit upon the mass of the people". ${ }^{51}$

Menurut Dicey, tipe ideal dari konstitusi yang 'seimbang' adalah eksekutif dapat ikut campur dalam hak individu, namun di satu sisi tunduk pada kontrol politik dari parlemen, dan di sisi lain, tunduk pada kontrol hukum dari pengadilan. Hal ini sesuai dengan doktrin kembar Dicey mengenai rule of law dan kedaulatan parlemen dimana kesimbangan terjadi pada pemerintahan yang terwakili. Pada akhir abad 19, pernyataan Dicey mengalami perubahan mengenai doktrin rule of law yaitu: '(i) that the state possesses no

2, 18 January 2011 diunduh dari: <http://onlinelibrary.wiley.com/doi/10.1111/j.1468-2230.1985.tb 00837.x/pdf >, diakses tanggal 26 Juni2013.

${ }^{49}$ Review: Forever Amber?, Law and Administration, by C. Harlow and R. Rowlings, "Theory of Administrative Law Notes", dinduh dari: <http://www.oxbridgenotes.co.uk/notes/oxbridge/2014/ administrative-law-notes>, diakses tanggal 26 Juni2013.

${ }^{50}$ Carol Harlow and Richard Rawlings, "Law and Administration”, (USA: Cambridge University Press, 2009), hal. 1.

${ }^{51}$ Ibid., hal. 2-3. 
'exceptional' powers and (ii) that individual public servants are responsible to (iii) the ordinary courts of the land for their use of statutory powers. ${ }^{52}$

Pendapat Dicey tersebut merupakan model yang bertolak belakang dari Green Light Theory yaitu Red Light Theory. Walaupun demikian, masingmasing teori berkembang bersamaan dengan kemunculan negara modern. Kedua teori tersebut menggambarkan apa yang dimaksud dengan hukum administrasi negara dan bagaimana harus bertindak dalam perannya di masyarakat. Berbeda dengan Harlow dan Rawlings, Peter Leyland dan Terry Woods berpendapat bahwa kedua teori tersebut dapat digunakan sebagai model untuk melihat bahwa aktivitas hukum sehari-hari merupakan kontinuitas dari asumsi yang berkembang mulai dari spektrum Red Light Theory sampai Green Light Theory. ${ }^{53}$

Penelitian ini juga akan menggunakan model pilihan rasional yang diaplikasikan dalam teori pilihan publik. $^{54}$ Dalam pengambilan keputusan efektivitas dari tujuan tertentu atau seperangkat tujuan sangat dipertimbangkan untuk memberikan penjelasan kepada individu dan apa yang seharusnya dilakukan dalam melihat tingkah laku manusia. Teori ini pertama kali dikenal dalam bidang mikro ekonomi atau statistik pengambilan keputusan yang kemudian berkembang dari asumsi dasar bahwa keputusan adalah pilihan yang sengaja diambil berdasarkan informasi, pihak yang tidak memiliki kepentingan, yang bekerja dengan seperangkat tujuan individu atau kelompok. ${ }^{55}$

Pengambilan keputusan dalam hal ini dilakukan dengan penuh kesadaran dan merupakan kegiatan yang konsisten dengan rasionalitas individu. Asumsi lain yang dipertimbangkan oleh model teori ini adalah pembuat keputusan melihat kemungkinan hasil dari setiap tindakan yang mungkin dilakukan dalam berbagai situasi. Lebih lanjut, konsekuensi dari keputusan dianggap sudah dapat diantisipasi dan pembuat keputusan dinilai telah memilih alternatif yang paling mungkin untuk mencapai tujuan yang diinginkan. ${ }^{56}$

Pilihan mengimplikasikan seperangkat alternatif. Menurut teori klasik dari pilihan rasional, diasumsikan bahwa proses pengambilan keputusan melibatkan pencarian pilihan diantara alternatif yang ada, tanpa mempertimbangkan keterbatasan dalam kapasitas manusia ketika memproses banyak informasi. Herbert A. Simon dalam bukunya Administrative Behaviour melakukan modifikasi terhadap ide pilihan rasional itu dengan menyarankan

${ }^{52}$ Ibid., hal. 6.

${ }^{53}$ Peter Leyland and Terry Woods, "Textbook on Administrative Law", 4th Edition, (Oxford University Press, 2002), hal. 5.

${ }^{54}$ Public choice is best defined as the application of the rational choice model to non-market decision-making. In a more general sense, it has meant the application of economics to political science. Lihat P.J. Hill, "Public Choice: A Review, Faith \& Economics", Number 34, Fall 1999, page 1-10.

${ }^{55}$ Keith Hawkins, "The Use of Legal Discretion: Perspective from Law and Social Science", The Use of Discretion, ed. Keith Hawkins, (New York: Oxford University Press Inc., 1992), hal. 11-46.

${ }^{56}$ Ibid., hal. 20. 
bahwa rasionalitas sesungguhnya terikat, bahwa manusia tidak bertindak hanya berdasarkan rasional semata ketika membuat keputusan. ${ }^{57}$

Sebagai hasilnya, menurut Simon, pembuat keputusan umumnya mencari diantara alternatif pilihan kecuali ketika ditemukan alternatif yang lebih baik, biasanya dipengaruhi oleh keputusan sebelumnya dan praktek yang sudah ada. Kegunaan teori ini bermacam-macam salah satunya dengan memahami diskresi. Beberapa perilaku pembuat keputusan individu yang dilakukan pelaku hukum seperti pengacara dapat dijelaskan dengan teori ini misalnya bagaimana memutuskan apakah akan menyelesaikan perkara didalam atau diluar persidangan. Sedangkan model lain misalnya dalam birokrasi, sangat sulit mengasumsikan bahwa semua pihak yang terlibat mengerti konsep mandat yang mereka terima (walau konsepnya diasumsikan sudah jelas) atau secara konsisten berusaha mencapai tujuan bersama. Logika dari teori ini adalah berasumsi bahwa konsep kepentingan yang dimiliki pembuat keputusan adalah sejalan dengan kepentingan organisasinya dan juga keputusan yang mereka ambil bukan berdasarkan informasi yang hanya demi kepentingan sendiri, ekonomi atau politik tertentu. ${ }^{58}$

Penggunaan teori rasional pilihan sangat terkait dengan situasi dimana pembuat kebijakan perlu mengambil keputusan sehingga akan terlihat rasionalitas dari kebijakan yang dipilih apakah dilakukan sesuai dengan ketentuan yang berlaku. Dalam konteks kebijakan bailout Bank Century, rasionalitas pilihan tersebut akan menentukan akuntabilitas dari keputusan KSSK. Hal tersebut bisa dijelaskan lebih lanjut melalui Behavioral Finance Theory (BFT).

BFT dibangun atas dua pilar yaitu keterbatasan melakukan arbitrase dan psikologi investor. Intinya, berlawanan dengan asumsi standard finance. Jika pada standard finance, pelaku ekonomi diasumsikan berperilaku rasional, maka akibat keterbatasan arbitrase, pelaku ekonomi berperilaku tidak rasional. Selain itu, jika standard finance berasumsi pelaku ekonomi memiliki kemampuan tidak terbatas dalam mencari dan memproses informasi, maka akibat pengaruh psikologi investor, keputusan investor selalu dipengaruhi bias psikologis tersebut. Hal inilah yang menyebabkan mengapa pelaku ekonomi berperilaku tidak rasional dan mengambil keputusan berdasar rumor. ${ }^{59}$

\section{Penemuan Hukum}

Terkait kerangka teori yang digunakan dalam penelitian ini, Sidharta ${ }^{60}$ berpendapat kaum utalitarian dapat dimasukkan ke dalam golongan positivisme

${ }^{57}$ Ibid., hal. 23.

${ }^{58}$ Ibid., hal. 24.

${ }^{59}$ Sawidji Widoatmodjo, "Mencari Kebenaran Objektif Dampak Sistemik Bank Century Kajian Teoritis dan Empiris”, (Jakarta: Kompas Gramedia, 2010), hal. 17. 
hukum karena secara ontologis keduanya memiliki pandangan yang sama tentang hukum sebagai norma positif dalam sistem perundang-undangan. Berbeda dengan positivisme hukum sebagaimana diusung oleh kaum Kelsenian, aliran berpikir positivisme dari kaum utilitarian memandang hukum tidak sekadar mementingkan tujuan kepastian hukum. Jika norma positif hanya diarahkan pada pencapaian kepastian, maka pekerjaan hukum telah berakhir begitu suatu keputusan/putusan hukum telah selesai ditetapkan. Utilitarianisme memandang dimensi kemanfaatan dari keputusan/putusan itu juga perlu diperhatikan untuk mengukur seberapa jauh keberlanjutan suatu norma positif dapat terus dipertahankan.

Pada saat norma positif diterapkan ke dalam kasus konkret, maka arah penegakan hukum ini masih sama dengan positivisme hukum. Dalam utilitarianisme, penalaran ini belum selesai karena masih ada tujuan lain dari hukum yang harus diakomodasi yakni nilai kemanfaatan. Nilai ini tidak mungkin dapat dicapai secara apriori, melainkan harus dieksperimenkan melalui pengalaman empiris. Pengalaman inilah yang akhirnya dapat menunjukkan apakah hukum yang baik itu benar-benar dapat memberikan kemanfaatan kepada sebanyak mungkin orang. ${ }^{61}$ Skema berikut merupakan adaptasi dari skema Sidharta:

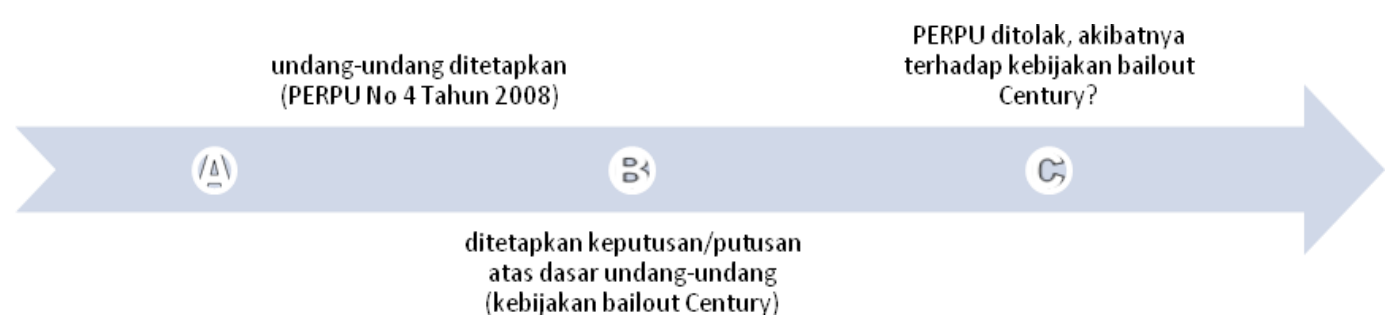

Jika diilustrasikan menjadi sebagai berikut: perjalanan sebuah undangundang dapat digolongkan kedalam tiga zona waktu. Zona A adalah suasana ketika sebuah undang-undang tengah digodok untuk akhirnya ditetapkan berlaku sebagai norma positif yang mengikat semua orang; zona B adalah ketika undang-undang itu berlaku sampai akhirnya muncul suatu kasus konkret yang menjadi aktivator penerapan undang-undang tersebut. Terhadap kasus itu lalu dikeluarkan keputusan berdasarkan undang-undang tadi.

Dalam perspektif positivisme hukum (ala Kelsenian), fokus perhatian diberikan sepenuhnya pada aktivitas di zona B. Zona ini merupakan zona penerapan sebuah undang-undang. Namun, bagi kaum utilitarian, selain zona $\mathrm{B}$, zona $\mathrm{C}$ juga harus ikut diperhitungkan. Jika zona $\mathrm{C}$ tersebut diartikan sebagai zona evaluatif untuk memperbarui sebuah undang-undang, maka

60 Shidarta, "Pemetaan Aliran-aliran Pemikiran Hukum dan Konsekuensi Metodologisnya, Metode Penelitian Hukum: Konstelasi dan Refleksi", ed. Sulistyowati Irianto dan Shidarta (Jakarta, Yayasan Pustaka Obor Indonesia, 2011), hal. 150-169.

${ }^{61}$ Ibid., hal. 164. 
sesungguhnya zona $\mathrm{C}$ adalah sebuah konteks penemuan bagi lahirnya undangundang yang baru. Zona $\mathrm{C}$ dengan demikian adalah zona A periode kedua: ${ }^{62}$

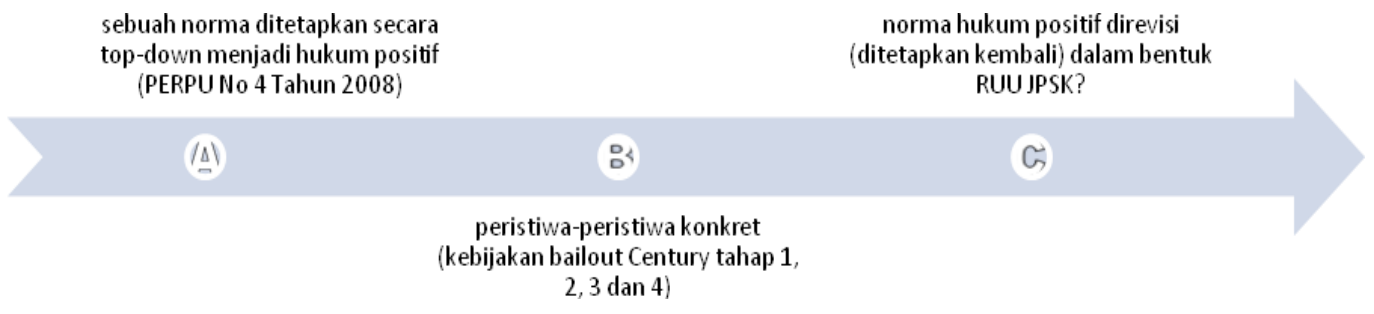

\section{Penutup}

Riset ini telah dimulai 5 tahun kebelakang oleh peneliti ketika menulis tesis tentang "Release and Dischrarge sebagai Alternatif Penyelesaian Masalah (Studi Kasus BLBI)". Pada waktu itu, kebijakan Bantuan Likuiditas Bank Indonesia (BLBI) yang merupakan alternatif penyelesaian masalah bagi obligor BLBI yang tidak mampu membayar dikarenakan krisis moneter 1997/1998, saat ini kembali dipermasalahkan. ${ }^{63}$

Dalam konteks kepastian hukum, pejabat tata usaha negara yang tidak berani mengambil keputusan dikarenakan resiko pertanggungjawaban pribadi akan menimbulkan kekosongan hukum. Oleh karena itu, penelitian ini menjadi penting untuk dilakukan ketika krisis ekonomi kembali membutuhkan kebijakan penanganan krisis yang cepat dan sesuai dengan asas-asas pemerintahan umum yang baik.

Penelitian ini juga diharapkan dapat menjadi landasan hukum yang kuat bagi para pemangku kebijakan untuk mengambil keputusan di masa depan terutama terkait penanganan krisis. Siklus yang selalu berputar membuat situasi yang sama sangat dimungkinkan untuk terulang kembali sehingga dibutuhkan kepastian hukum untuk mengatasinya.

${ }^{62}$ Ibid., hal. 166.

${ }^{63}$ Komisi Pemberantasan Korupsi kembali meminta keterangan mantan Menteri Koordinator Bidang Perekonomian Dorodjatun Kuntjoro-Jakti, Jumat (12/12/2014). Dorodjatun diperiksa terkait penyelidikan atas penerbitan surat keterangan lunas (SKL) beberapa obligor Bantuan Likuiditas Bank Indonesia (BLBI). Diunduh dari: <http://nasional.kompas.com/read/2014/12/12/17495731/Penyelidikan. SKL.BLBI.Dorodjatun.Kembali.Dimintai.Keterangan>, diakses tanggal 1 Oktober 2014. 


\section{Daftar Pustaka}

\section{Buku}

Asshiddiqie, Jimly. Hukum Tata Negara Darurat, Jakarta: PT RajaGrafindo Persada, , 2007.

Barnett, Hilaire. Constitutional and Administrative Law, Queen Mary: University of London, Routledge Cavendish, 2006.

Departemen Keuangan RI. Buku putih, Upaya Pemerintah dalam Pencegahan dan Penanganan Krisis, Departemen Keuangan RI, Januari 2010.

Chinhengo, Austin M. Essential Jurisprudence, Essential Law Series, Cavendish Publishing Limited, The Glass House, Wharton Street, London, 1995.

Davis, Kenneth Culp. Discretionary Justice: A Preliminary Inquiry, University of Illinois Press, 1971

Efendi, Maftuh. Kewenangan Uji Materiil Peraturan Perundang-Undangan: Kajian Tentang Putusan Mahkamah Agung RI Tahun 2005-2011. Laporan Penelitian, Pusat Penelitian dan Pengembangan Mahkamah Agung RI, 2013.

Freeman, M.D.A. Lloyd's Introduction to Jurisprudence, London: Sweet \& Maxwell ltd., 2011.

Hadjon, Philipus M. Pemerintahan Menurut Hukum (Wet-En Retchmatig Bestuur), Surabaya: Yuridika, 1993.

Harlow, Carol dan Richard Rawlings. Law and Administration, second edition, Cambridge University Press, 1997.

Hawkins, Keith. The Use of Legal Discretion: Perspective from Law and Social Science, The Use of Discretion, ed. Keith Hawkins, New York: Oxford University Press Inc., 1992.

Hoesein, Zainal Arifin. Judicial Review di Mahkamah Agung RI Tiga Dekade Pengujian Peraturan Perundang-undangan, Jakarta: PT RajaGrafindo Persada, 2009.

Ibrahim, Johny. Teori dan Metodologi Penelitian Hukum Normatif, Malang: Bayumedia Publishing, 2006.

James, E. Anderson. Public Policy Making, cet. ke-3, New York, Holt, Rinehart and Winston, 1984.

Kelsen, Hans. General Theory of Law and State yang dialihbahasakan oleh Somardi. Teori Umum Hukum dan Negara Dasar-dasar Ilmu Hukum Normatif sebagai Ilmu Hukum yang Deskriptif-Empirik, Bee Media Indonesia, 2007.

Leyland, Peter. Textbook on Administrative Law, Oxford University Press, tt. 
Lorch, Robert S. Democratic Process \& Administrative Law, Detroit 1969.

Osborne, David dan Ted Gaebler. Reinventing Government: How the Entrepreneurial Spirit is Transforming the Public sector. AddisonWesley Publ. Co., 1992.

Parsons, Wayne. Public Policy Pengantar Teori dan Praktek Analisis Kebijakan, Jakarta: Kencana, 2005.

Ridwan HR. Hukum Administrasi Negara, Jakarta: PT RajaGrafindo Persada, 2006.

Tiga Dimensi Hukum Administrasi dan Peradilan Administrasi, Yogyakarta, FH UII Press, 2009.

Purbopranoto, Kuntjoro. Beberapa Catatan Hukum Tata Pemerintahan dan Peradilan Administrasi Negara, Bandung: Penerbit Alumni, 1985.

Putri, Trikaloka. Kamus Perbankan, Mitra Pelajar, Yogyakarta. 2009.

SF Marbun dkk. Dimensi-Dimensi Pemikiran Hukum Administrasi Negara, Yogyakarta, UII Press, 2001.

Shidarta. "Pemetaan Aliran-aliran Pemikiran Hukum dan Konsekuensi Metodologisnya", Metode Penelitian Hukum: Konstelasi dan Refleksi, ed. Sulistyowati Irianto dan Shidarta Jakarta, Yayasan Pustaka Obor Indonesia, 2011.

"Penelitian Hukum Normatif: Analisis Penelitian Filosofikal dan Dogmatikal", Metode Penelitian Hukum: Konstelasi dan Refleksi, ed. Sulistyowati Irianto dan Shidarta (Jakarta, Yayasan Pustaka Obor Indonesia, 2011).

Soekanto, Soerjono. Pengantar Penelitian Hukum, Jakarta: Universitas Indonesia, 1982.

Utrecht. E. Pengantar Hukum Administrasi Negara Indonesia, Surabaya, Pustaka Tinta Mas, 1988.

Wignjosoebroto, Soetandyo. "Penelitian Hukum dan Hakikatnya sebagai Penelitian Ilmiah", Metode Penelitian Hukum: Konstelasi dan Refleksi, ed. Sulistyowati Irianto dan Shidarta (Jakarta, Yayasan Pustaka Obor Indonesia, 2011).

\section{Koran}

"Centurygate: Mengurai Konspirasi Penguasa-Pengusaha", Kompas, Jakarta, April 2010.

Prasetyantoko, Arief. "Ponzi Ekonomi: Prospek Indonesia di Tengah Instabilitas Global”, Kompas, Jakarta, November 2010. 


\section{Jurnal}

Arthurs, Harry W. "Rethinking Administrative Law: A Slightly Dicey Business", Osgoode Hall Law School, Vol. 17, No. 1 (April 1979).

Barkow, Rachel E. "Institutional Design and The Policing of Prosecutors: Lessons from Administrative Law”, New York University Public Law and Legal Theory, Working Paper No. 69, Maret 2008.

Barr, Michael S. and Geoffrey P. Miller. "Global Administrative Law: The View From Basel", The European Journal of International Law, Vol. 17, No. 1, 2006.

Benjamin, Stuart Minor and Arti K. Rai. "Who's Afraid of the APA? What The Patent System Can Learn from Administrative Law”, The Georgetown Law Journal, Vol. 95: 269-336, 2007.

Benvenisti, Eyal. "The Interplay Between Actors as A Determinant of The Evolution of Administrative Law in International Institutions", Law and Contemporary Problems, Vol. 68: 319-340, 2005.

Bovens, Mark dan Stavros Zouridis. "From Street-Level to System-Level Bureaucracies: How Information and Communication Technology Is Transforming Administrative Discretion and Constitutional Control", Public Administration Review, Vol. 62, No. 2, March/April 2002.

Bressman, Lisa Schultz. "Procedures as Politics in Administrative Law", Columbia Law Review, Vol. 107, No. 8, Desember 2007.

Calavita, Kitty and Henry N. Pontell, 1994, "The State and White-Collar Crime: Savings the Savings and Loans", Law \& Society Review Vol. 8 No. 2.

Clagett, Brice McAdoo. "Informal Action-Adjudication-Rule Making: Some Recent Developments in Federal Administrative Law", Duke Law Journal, Vol. 1971:51-88.

Coglianese, Cary. "Empirical Analysis and Administrative Law", University of Illinois Law Review, No. 4, Vol. 2002: 1111-1138.

Cohen, Leonard E. "Some Aspects of Maryland Administrative Law", Maryland Law Review, Vol. 24, No. 1, Winter 1964.

Criddle, Evan J. "Fiduciary Foundations of Administrative Law", HeinOnline, 54 UCLA L. Rev. 117, 2006-2007.

Elliott, E. Donald and Peter H. Schuck. "To The Chevron Station: An Empirical Study of Federal Administrative Law", HeinOnline, 1990, Duke L. J.

Epstein, David dan Sharyn O'Halloran. "Administrative Procedures, Information and Agency Discretion", American Journal of Political Science, Vo. 38, No. 3 (Aug,. 1994), 697-722. 
Fisse, W.B. 1977-1978, “The Social Policy of Corporate Crime Responsibility”, The Adelaide Law Review. 6 Adel. L. Rev. 31.

Goodnow, Frank J. "Private Rights and Administrative Discretion", American Bar Association Journal, Vol. 2, No. 4 (October, 1916), pp. 789-804.

Grey, J.H. "Discretion in Administrative Law", Osgoode Hall Law Journal, Vol. 17, No. 1, April 1979.

Harlow, Carol. Global Administrative Law: The Quest For Principles and Values, The European Journal of International Law, Vol. 17, No. 1, 2006.

Harten, Gus Van and Martin Loughlin. Investment Treaty Arbitration as a Species of Global Administrative Law, The European Journal of International Law, Vol. 17, No. 1, 2006.

K. Calavita, R. Tillman, H. N. Pontell,1997, "The Savings and Loan Debacle, Financial Crime and the State”, Annual Review of Sociology, Vol. 23, pp. 19-38.

Kingsbury, Benedict and Nico Krisch and Richard B. Stewart. The Emergence of Global Administrative Law, New York University Public Law and Legal Theory Working Paper, Paper 17, 2005.

Koch Jr. Charles H. Judicial Review of Administrative Discretion, William \& Mary Law School, 1986.

Levin, Ronald M. "Vacation" at Sea: Judicial Remedies and Equitable Discretion in Administrative law, Duke Law Journal, Vol. 53, No. 2, November 2003.

Li-ann, Thio. The Theory and Practice of Judicial Review of Administrative Action in Singapore, SAL Conference 2011 - Singapore Law Developments (2006-2010).

Isaacs, Nathan. Judicial Review of Administrative Findings, The Yale Law Journal, Vol. 30, No. 8 (Jun., 1921), pp. 781-797.

Lysestol, Peder Martin. 2007/2008, "Neo-classical Economic Policy and Social Justice", IUC Journal of Social Work Theory and Practice, Journal Isssue 15.

Mashaw, Jerry L. Reinventing Government and Regulatory Reform: Studies in The Neglect and Abuse of Administrative Law, HeinOnline, U. Pitt. L. Rev. 405, 1995-1996.

Mashaw, Jerry L. Recovering American Administrative Law: Federalist Foundations, 1787-1801, The Yale Law Journal, Vol. 115: 1256, 2006.

Mashaw, Jerry L. Reluctant Nasionalists: Federal Administration and Administrative Law in The Republican Era, 1801-1829, The Yale Law Journal, Vol. 116: 1636, 2007. 
McCubbins, Mathew D. and Roger D. Noll and Barry R. Weingast. Administrative Procedures as Instruments of Political Control, Journal of Law, Economics, \& Organization, Vol. 3, No. 2 (Autumn, 1987), pp. 243-277.

Metzger, Gillian E. Ordinary Administrative Law as Constitutional Common Law, Journal of The National Association of Administrative Law Judiciary, Vol. 30, Issue 2, 2010.

Muhlizi, Arfan Faiz. "Reformulasi Diskresi dalam Penataan Hukum Administrasi”, Jurnal Rechtsvinding, Vol. 1, No. 1, April 2012.

Mustamu, Julista. "Diskresi dan Tanggung Jawab Administrasi Pemerintahan", Jurnal Sasi, Vo. 17, No. 2, April-Juni 2011.

Nalle, Victor Imanuel W., "Kewenangan Yudikatf dalam Pengujian Peraturan Kebijakan, Kajian Putusan No 23 P/HUM/2009", Jurnal Yudisial, Volume 6 No 1 April 2013, Hal. 33-47.

Paternoster, Raymond dan Sally Simpson. 1996, "Sanction Threats and Appeals to Morality: Testing a Rational Choice Model of Corporate Crime”, Law \& Society Review, Vol. 30, No. 3, pp. 549-583.

Pierce Jr. Richard J. "Two Problems in Administrative Law: Political Polarity on The District of Columbia Circuit and Judicial Deterrence of Agency Rulemaking”, Duke Law Journal, Vol. 1988: 300-328.

Posner, Richard A. "The Rise and Fall of Administrative Law", Chicago-Kent Law Review, Vol. 72: 953-963, 1997.

Prakoso, Abintoro. "Vage Normen sebagai Sumber Hukum Diskresi yang Belum Diterapkan oleh Polisi Penyidik Anak", Jurnal Hukum No. 2, Vol. 17, April 2010: 249-270.

Rogers, Patricia J. 2004, “Accountability”, Encyclopedia of Evaluation. SAGE Publications. Article no 4.

Rose-Ackerman, Susan. "Progressive Law and Economics-and The New Administrative Law", HeinOnline, 98 Yale L. J. 341, 1988-1989.

. "American Administrative Law Under Siege: Is Germany a Model?", HeinOnline, 107 Harv. L. Rev. 1279, 1993-1994.

Scalia, Antonin. "Judicial Deference to Administrative Interpretations of Law”, Duke Law Journal, No. 3, Vol. 1989:511-521.

Schiller, Reuel E. "Enlarging the Administrative Polity: Administrative Law and The Changing Definition of Pluralism", 1945-1970, 53 Vand. L. Rev. 1389, 2000.

Shapiro, Martin. "Administrative Discretion: The Next Stage", HeinOnline, 92 Yale L.J 1487, 1982-1983. 
Shapiro, Sidney A dan Robert L. Glickmans. "Congress, The Supreme Court and The Quiet Revolution in Administrative Law", Duke Law Journal, Vol. 1988: 819-878, No. 5.

Shavell, Steven. 1995, "Alternative Dispute Resolution: An Economic Analysis", The Journal of Legal Studies, Vol. 24, No. 1, pp. 1-28.

Smith, Loren A. "Judicialization: The Twilight of Administrative Law", Duke Law Journal, Vol. 1985:427-466.

Spahr, Lisa L. dan Laurence J. Allison. "US Savings and Loans Fraud: Implications For General And Criminal Culture Theories Of Crime”, Crime, Law and Social Change, 41: 95-106, Kluwer Academic Publisher, 2004.

Strauss, Peter L. Overseer or "The Decider"? The President in Administrative Law, The George Washington Law Review, Vol. 75: 696-760, 2007.

Stewart, Richard B. Regulation, "Innovation and Administrative Law: A Conceptual Framework", California Law Review, Vol. 69, Issue 5, September 1981.

"Administrative Law in The Twenty-First Century", New York University Law Review, Vol. 78, No. 2, May 2003.

"U.S. Administrative Law: A Model for Global Administrative Law?", Law and Contemporary Problems, Vol. 68: 63108, 2005.

Sunstein, Cass R. "Administrative Law Goes To War, Chicago Public Law and Legal Theory", Working Paper No 90, The Law School The University of Chicago, May 2005.

The Yale Law Journal Company, Inc. "Judicial Review of Administrative Determinations", The Yale Law Journal, Vol. 27, No. 4 (Feb., 1918), pp. 550-553.

Zywicki, Todd. "The Auto Bailout and The Rule of Law", National Affairs Journal, Issue Number 7 Spring 2011.

"Review: Forever Amber?, Law and Administration" by C. Harlow and R. Rowlings, The Modern Law Review, Volume 8 issue 2, 18 January 2011 diunduh dari: <http://onlinelibrary.wiley.com/doi/10.1111/j.1468-2230. 1985.tb00837.x/pdf>, diakes tanggal 1 Oktober 2014.

"Theory of Administrative Law Notes", diunduh dari: <http://www.oxbridgenotes.co.uk/notes/oxbridge/2014/administrativelaw-notes/samples/theory-of-administrative-law>, diakes tanggal 1 Oktober 2014. 


\section{Artikel}

Adair-Toteff, Christopher. Andreas Anter, "Max Weber's Theory of the Modern State", diunduh dari: <http://theoryculturesociety.org/review-ofmax-webers-theory-of-the-modern-state/>, diakes tanggal 1 Oktober 2014.

Bader, Hans. "Bailout Threatens Economy, Shreds Constitution, Rips Off Taxpayers", diunduh dari: <http://cei.org/blog/bailout-threatenseconomy-shreds-constitution-rips-taxpayers>, diakes tanggal 1 Oktober 2014.

. "Court Rebuffs Challenge to Illegal Chrysler Bailout and Takeover; Pension Funds Will Appeal to Supreme Court", diunduh dari: $<$ http://cei.org/blog/court-rebuffs-challenge-illegal-chrysler-bailout-andtakeover-pension-funds-will-appeal-supreme>, diakes tanggal 1 Oktober 2014.

Effendi, Sofian. "Membangun Good Governance: Tugas Kita Bersama", diunduh dari <http://sofian.staff.ugm.ac.id/artikel/membangun-goodgovernance.pdf>, diakes tanggal 26 Juni 2013.

Ewing, Jack. "German Court Validates Participation in Euro Zone Bailout Fund", diunduh dari: <http://www.nytimes.com/2014/03/19/business/ international/german-court-validates-participation-in-euro-zone-bailoutfund.html?_r=0>, diakes tanggal 1 Oktober 2014.

Ferly, Mahfud. "MK Dapat Uji Konstitusionalitas Perpu", diunduh dari: $<$ http://www.antara.co.id/berita/1265672941/mahfud-mk-dapat-ujikonstitusionalitas-perpu>, diakes tanggal 1 Oktober 2013.

Kalsum, Umi dan Agus Dwi Darmawan serta Anggi Kusumadewi. "Rincian 23 Aliran Dana LPS untuk Century", diunduh dari: $<$ http://bisnis.news.viva.co.id/news/read/108042-incian_23_aliran_dana _lps_untuk_century>, diakes tanggal 1 Oktober 2013.

Mulyani, Sri. kutipan dalam berita "Apa Kabar Indonesia", Selasa, 1 September 2009, Tvone.

Painter, Richard. "Bailouts and Government Ethics", 26 Maret 2009, diunduh dari: <http://volokh.com/archives/archive_2009_03_22-2009_03_28. shtml\#1238043132>, diakes tanggal

Priatmojo, Dedy dan Taufik Rahadian. "KPK: Kebijakan Bailout Century Hanya Cover Tutupi Pidana”, diunduh dari: <http://nasional.news.viva. co.id/news/read/488547-kpk--kebijakan-bailout-century-hanya-covertutupi-pidana>, diakes tanggal 1 Oktober 2014.

Pringgodigdo, R.M. Girindro. "Kebijaksanaan, Hirarkhi Perundang-Undangan dan Kebijakan dalam konteks Pengembangan Hukum Administrasi Negara di Indonesia", Pidato Pengukuhan diucapkan pada penerimaan 
jabatan sebagai Guru Besar Tetap Ilmu Hukum pada FHUI di Balai Sidang UI, Rabu 16 November 1994.

Satter, Marlene Y. Dutch Bailouts of ING, ABN Amro 'Large Errors': Committee, ThinkAdvisor, 11 April 2012.

Simatupang, Dian Puji N., Kebijakan Sebagai Produk Administrasi Negara: Dapatkah Dipidanakan?, Paparan dalam seminar, "Pengambilan Kebijakan Publik Patutkah Dipidana?" pada Program Pascasarjana Fakultas Hukum Universitas Indonesia, Jakarta, 8 Maret 2014

Soebroto, Arif Christiono Soebroto. "Kedudukan Hukum Peraturan/Kebijakan Dibawah Peraturan Menteri Perencanaan Pembangunan Nasional/ Kepala Bappenas", diunduh dari <http://birohukum.bappenas. go.id/data/data_berita/WORKSHOP\%20Peraturan\%20kebijakan\%20di\% 20Kementerian\%20PPN\%20\%20bappenas.pdf>, diakes tanggal 26 Juni 2013.

Soeprijanto, Totok. "Apakah Kebijakan Dapat Dipidana?", diunduh dari: <http://www.bppk.depkeu.go.id/webpegawai/attachments/442_Apakah\% 20kebijakan\%20dapat\%20dipidana\%20TS\%20REV.pdf>, diakes tanggal 7 Desember 2013.

"Hakim Tepis Analogi Boediono soal Century ibarat Memadamkan Rumah Terbakar", diunduh dari: <http://nasional.kompas.com/read/2014/07/16/ 18262601/Hakim.Tepis.Analogi.Boediono.soal.Century.ibarat.Memadam kan.Rumah.Terbakar>, diakes tanggal 1 Oktober 2014.

"Sri Mulyani bersaksi pada sidang Bank Century", diunduh dari:http://www.bbc.co.uk/indonesia/berita_indonesia/2014/05/140502_si dang_srimulyani_saksi_bankcentury, diakes tanggal 1 Oktober 2014.

"Jusuf Kalla bersaksi di sidang Bank Century", diunduh dari: http://www.bbc.co.uk/indonesia/berita_indonesia/2014/05/140508_yusuf _kalla_saksi_bankcentury, diakes tanggal 1 Oktober 2014.

\section{Peraturan Perundang-Undangan}

UU No 30 Tahun 2014 Tentang Administrasi Pemerintahan

PERPU No 4/2008 tentang JPSK

Putusan MA No 572K/Pid/2003, diunduh dari: <http://putusan.mahkamahagung.go.id/putusan/24548>, diakes tanggal 7 Desember 2013.

UU No 28/1999 tentang Penyelenggaraan Negara yang bersih dan bebas dari KKN.

UU No 17 tahun 2003 tentang Keuangan Negara

UU No 24 tahun 2004 tentang LPS 
Keputusan No 04/KSSK.03/2008 tentang Penetapan Bank Century sebagai Bank Gagal yang Berdampak Sistemik. 